В. В. КРИЖЕВСЬКИЙ ${ }^{1,2}$, О. О. ЦИГАНЕНКО ${ }^{2}$, М. В. ШЕВЧУК², Ю. В. РИБ'ЯНЕЦЬ ${ }^{2}$, Р. В. ІВАНЧЕНКО², І. М. ЩЕГОЛЬ ${ }^{1}$, Н. Л. ТОАН ${ }^{2}$, Т. М. ПИЛИПЕНКО

Київська міська клінічна лікарня № $6^{1}$

Національна медична академія післядипломної освіти імені П. Л. Шупика², Київ

Національний технічний університет України "Київський політехнічний інститут імені Ігоря Сікорського"з

\title{
Огляд консервативних методів лікування у хворих на оніхокриптоз
}

\begin{abstract}
Наведено приклад використання малоінвазивних методів лікування - ортоніксія (3TO, титанова нитка, L-вкладка, ARKADA) при лікуванні оніхокріптозу (врослого нігтя). Малоінвазивні ортоніксичні методи застосовували на базі Київської міської клінічної лікарні № 6 протягом 2012-2018рр. Досягнуто повне відновлення нігтьової пластини і усунення вростання нігтьових пластин при малоінвазивному ортоніксичному втручанні. Лікування врослого нігтя стає більш ефективним. Дані методики усувають недоліки інших систем і оперативних методик, оскільки одночасно діє на два патогенетичні фактори, а саме на нігтьову пластину, моделюючи її подальше зростання, і на нігтьові валики, формуючи їх анатомічно під фізіологічну форму нігтьової пластини. Спираючись на клінічний досвід лікарів Київської міської клінічної лікарні № 6 та співробітників кафедри загальної та невідкладної хірургії НМАПО імені П. Л. Шупика, можна сказати, що дані методики можуть застосовуватися в клінічній практиці лікарів України.
\end{abstract}

Ключові слова: оніхокриптоз; врослий ніготь; клінічний випадок; метод ARKADA.

Серед гнійно-септичних захворювань шкіри та підшкірно-жирової клітковини значне місце займає врослий ніготь (incamatio unguae, оніхокриптоз), який виникає внаслідок травмування матриксу нігтьової пластини та характеризується потовщенням і деформацією бокового краю, виникненням довго незагоюючих ранових дефектів $[1,2,3]$.

В останні роки, внаслідок різних обставин, кількість хворих на врослий ніготь не тільки не зменшилося, але й спостерігається зростання тенденції до числа хворих на дану патологію та нараховує 5-6 \% від загальної кількості населення або 20 \% від усіх амбулаторних (хірургічних) хворих [4].

Незважаючи на високу захворюваність, за медичною допомогою звертаються та отримують кваліфіковане хірургічне лікування не більше 1 \% хворих [5]. Ефективність сучасних методів лікування врослого нігтя залишається дуже низькою, про що свідчить, що 40-60 \% хворих із врослим нігтем звертаються до лікаря повторно [6].

Етіологічними чинниками виникнення врослого нігтя є різні фактори, а саме:

1. Мікротравма матриксу, внаслідок якої порушується мікроциркуляція та інервація в ростковій зоні нігтя. В середньому через 6 місяців після травми латеральна частина нігтя деформується у підошовному напрямку, з'являються перші ознаки врослого нігтя. Якщо враховувати анатомію та гістологію, оніхобласти нігтьової пластини діляться у напрямку до вільного краю нігтя, при обрізанні по прямій лінії ріст нігтя продовжується у напрямку дистального валика, а при закругленні його країв - у напрямку штучно створеного вільного краю.

2. Неправильне обрізання нігтьової пластинки під час виконання педикюру (як самостійного, так і в кабінеті педикюру).

3. Використання вузького взуття, незручного взуття, взуття на високих підборах, коли виникає перерозподіл навантаження маси тіла зі склепіння стопи на фаланги пальців, а особливо на I палець стопи.

4. Мікозне та інфекційне ураженння нігтьової пластинки [12].

5. Невиконання правил гігієни стопи.

6. Диспропорційне співвідношення між кістяком і м’якими тканинами стопи та пальців.

7. Важливим етіологічним чинником розвитку врослого нігтя $є$ різного роду ураження нервових стовбурів, нижніх кінцівок, середнього та великого калібру. Гостра та хронічна травма нервових закінчень призводить до трофічних порушень у тканинах кінцівки, на жаль, часто недооцінюються практикуючими лікарями [7]. Sadr B. Вказує на розвиток врослого нігтя, навіть у хворих після пересадки пальців [8].

8. Серед причин врослого нігтя виявляють функціональну слабкість стопи, яка призводить до ущільнення поперечного склепіння стопи з наступним формуванням вальгусного положення пальця [9, 10].

9. Відмороження [11].

За період з 2008-2012 pp., 2015р. та в 2017p. році в КМКЛ № 6 “Медмістечко” простежується досить динамічне зростання кількості пролікова- 
них хворих на врослий ніготь, проте в 2013 р., 2014 р. та 2016 р. кількість пролікованих хворих зменшилась, при порівняні із 2012 р., відповідно у 2013 р. кількість пролікованих хворих зменшилась на 8 \% а порівняно із 2012 р., у 2014 р. кількість пролікованих хворих зменшилась на 40 \% порівняно із 2012 р., у 2015 р. порівняно із 2014 р. кількість пролікованих хворих на врослий ніготь зросла 46,6 \% і становила 44 особи, проте дана кількість менша на 12 \% від кількості пролікованих хворих на врослий ніготь за 2012 р. у 2016 р. кількість хворих зменшилась порівняно із 2012 р. на 24 \%. Проте у 2017 р. кількість пролікованих хворих значно збільшилась на 56 \% порівняно із 2012 р. і становила 78 осіб. Збільшення кількості пролікованих хворих у 2017 р. пов'язане із:

- збільшенням кількості хворих на врослий ніготь, які потребували операційного та/або ортоніксичного лікування (із впровадженням нових методів лікування);

- впровадження в 2017 р. застосування нового алгоритму лікування хворих на врослий ніготь, який мав досить позитивні характеристики.

Середня тривалість перебування на листку непрацездатності в 2008 році 8,63 дня, в 2009 році 8,94 дня, 2010 рік - 7,85 дня, 2011 рік - 8,97 дня, 2012 рік - 7,48 дня, 2013 рік - 8,28 дня, 2014 рік - 8 днів, 2015 рік - 5,93 дня, 2016 рік - 5,6 дня, 2017 рік - 3,1 дня, за період 2008-2017 роки середній термін перебування на листі непрацездатності - 6,65 дня.

Лікування врослого нігтя (оніхокриптозу) поділяється на дві великі групи, а саме консервативне та хірургічне лікування. У свою чергу, консервативне лікування поділяється ще на дві групи, ті що безпосередньо впливають на нігтьову пластину (ортоніксія) та ті, що впливають на бокові валики та запалення.

Поняття “ортоніксія” приблизно в 1960 році ввів шотландський спеціаліст із догляду за стопою Росс Фрезер. Поняття “ортоніксія” складається з двох грецьких слів “оnyx”, яке перекладається як ніготь та “orthos”, що означає правильний, прямий. Тобто ортоніксія в перекладі з грецької мови “вирівнювання нігтя”.

Історія виникнення та розвитку ортоніксії почалася в 1873 р. та продовжується і до сьогодні: 1873 рік - перша проволочна скоба, патент $€$. Стедмана; 1938 рік - Розенштейн, два отвори, хірургічна нитка; 1946 рік - Шолль, стальна проволока, стандартний розмір, дві центральні петлі; 1960 рік - Гіффорд, трикомпонентна скоба з двома кінцевими ланками та варіабельною пружиною; 1962 рік - перша скоба Фрезера (Fraser 1), унілатеральна напівскоба; 1963 рік - друга скоба Фрезера (Fraser 2); 1964 рік - Вальдманн, двокомпонентна скоба: пластикова скоба для коррекції форми нігтя; 1986 рік - рейдинг, універсальні ступінчаті щипці для виготовлення скоби Фрезера; 1970 рік - Китцка, готова скоба Фрезера 11-25 мм; 1977 рік - Горгевич, плоска пружинна скоба без компенсаціонної петлі; 1982 рік - техніка Єркі, крючок з полімерного матеріала та пружини; 1982 рік - метод Link, регульована скоба; 1983 рік - повний протез нігтя Erkodent, штучний ніготь, удосконалення протезу Гренмайера (Greppmayer-Plattenprothese); 1987 рік скоба BS (Stolz); 1988 рік - скоба VHO-Spange (Osrhold), трикомпонентна скоба; 1990 рік - скоби Goldspange, Goldstandart-Spange (Ruck); 1990 рік - скоби Onyclip (Erkodent), металева пластина, яка зверху вкрита шаром пластику; 1992 рік скоба 3ТО-Spange, трикомпонента скоба; 1998 рік - титанова нитка (Японія); 2006 рік - скоба OraSpange (Rathenow), двокомпонентна скоба; 2007 рік - скоба Podofix-Aktiv-Klebspange (ЗТО), скоба з коробочкою, яка приклеюється до нігтя; 2010 рік - скоба Corectio titan (Японія); 2011 рік - скоба COMBIped, комбінує пружинну проволоку зі скобою на клеєвій основі; 2012 рік - скоба BS з магнітним аплікатором (Klebespange) [13]; 2012 рік - method ARKADA (Poland); 2016 рік - трикомпонентна скоба ЗТО Plus+; 2017 рік - скоба з титанової нитки NiTi Uno (Україна, патент на корисну модель № 115351 від 10.04.2017р.); 2017 рік корекція врослого нігтя за допомогою L-сегмента (Україна, патент на корисну модель № 117151 від 12.06.2017 р.); 2018 рік - скоба UniBrace (Poland).

На даний час у практиці активно застосовується декілька корекційних систем (ортоніксія), а саме титанова нитка (NiTi Uno), 3TO, L-вкладка, ARKADA, які ми розглядаємо в нашій публікації.

Усі корекційні системи поділяються на групи залежно від того, з якого матеріалу вони виготовлені. $€$ три основні різновиди матеріалу:

1. Нікель-титанова нитка.

2. Сталевий дріт (медична сталь).

3. Формування скоби з акрилових компонентів.

Нікель-титановий дріт для корекції врослого нігтя вперше у 1998 році запропонували японські вчені. Нікель-титанова дріт має надзвичайну якість - супереластичний, це означає, що сила дії дроту мало залежить від ступеня її вигину, що дозволяє працювати практично з постійним рівномірним зусиллям. На рисунку 1 зображена для порівняння суцільною лінією сила опору сталевого дроту і пунктирною лінією сила опору супереластичним нікель-титанового дроту однакового діа- 
метра залежно від ступеня деформації. У сталевого дроту (скоба 3ТО) йде різке зростання сили опору при деформації, в той же час нікель-титановий дріт при деформації (відносному подовженні) від 1,5 до 8 \% має постійну силу опору. При відносному подовженні понад 1,5-2 \% нержавіюча сталь миттєво руйнується, а нікель-титановий сплав не деформується. Ці унікальні властивості нікель-титану дозволили ефективно використовувати його при корекції врослих нігтів. Нікель-титанова нитка буде вирівнювати нігтьову пластину 3 постійним рівномірним зусиллям. Завдяки цьому не виникає стресового навантаження на нігтьову пластину, таким чином не виникає загроза оніхолізиса. У сталевій скобі, навпаки, спочатку дуже сильне навантаження на нігтьову пластину і потім вона перестає ефективно працювати. Крім того, видно, що сталь значно поступається за міцністю нікельтитану і відповідно за довготривалістю (рис. 1).

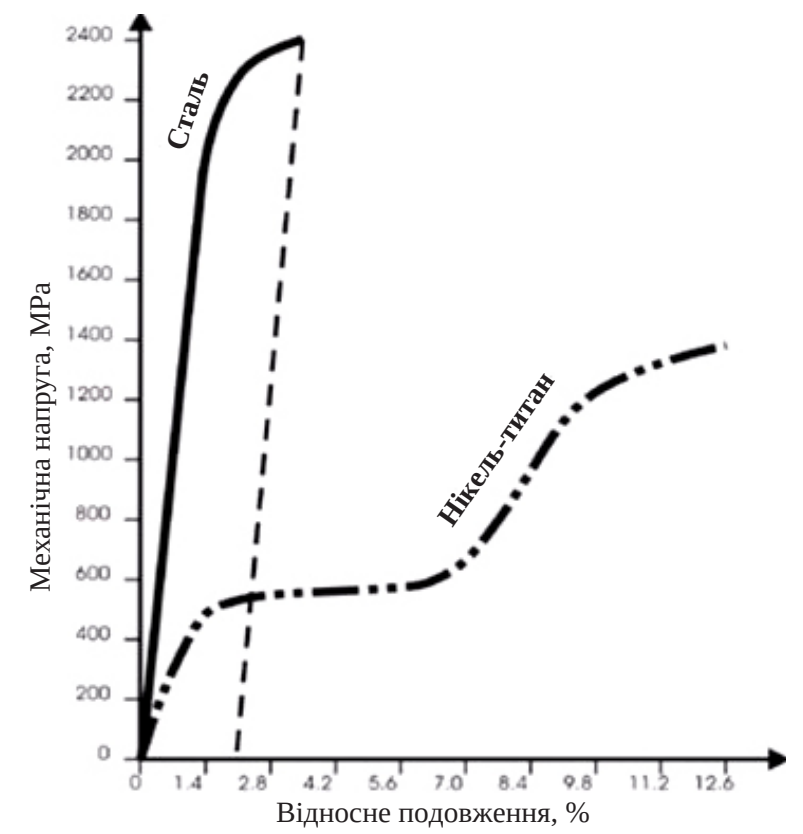

Рис. 1. Графік співвідношення міцності нікель-титану до медичної сталі.

Однак нікель-титановий дріт одного і того ж діаметру може працювати по-різному залежно від типу вигину.

Розглянемо задачу вигину NiTi дроту товщини і довжини, яку можна умовно поділити на три частини - це вигин прямого дроту, вигин прямого дроту з додатковим кріпленням в центрі, вигин сигмоподібного дроту (з радіусом круглої петлі) (рис. 2).

При установці на нігтьову пластину дріт зазнає деформації. Залежно від типу вигину дроту, він піддається різним видам деформації.

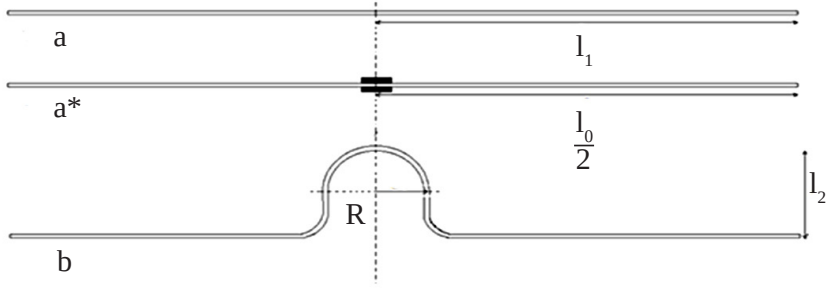

Рис. 2. Схематичне зображення дроту (вид звер$\mathrm{xy):} \mathrm{a} \mathrm{-} \mathrm{прямий} \mathrm{дріт;} \mathrm{a*} \mathrm{-} \mathrm{прямий} \mathrm{дріт} з$ додатковим кріпленням у центрі, b - сигмоподібний дріт.

Для прямого відрізка дроту (тип деформації дроту а й а *) виникає сила вигину, спрямована по осі Ү вгору.

При деформації дроту з сигмоподібним вигином виникають дві сили: сила вигину спрямована по осі Y вгору, інша-сила стиснення сигмоподібної ділянки дроту, направлена по осі $\mathrm{X}$ уздовж нігтьової пластини (рис. 3).

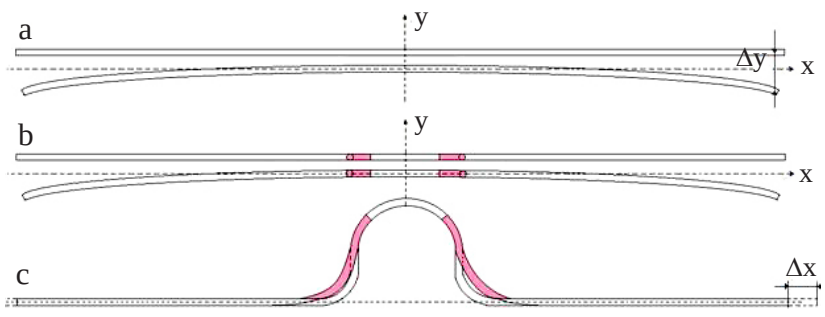

Рис. 3. Схематично зображені типи деформацій дроту (кольором виділено область, яка має деформацію), де $\Delta y$ - величина деформації (прогину дроту) по вертикалі $\Delta \mathrm{x}$ - величина деформації (розтягування дроту) по горизонталі та їх значення $(\Delta \mathrm{x}$ та $\Delta \mathrm{y})$ змінюється залежно від діаметра дроту.

Сила впливу дроту розраховується за законом Гука. Ця сила залежить від коефіцієнта жорсткості дроту, який розраховується з огляду на діаметр, довжину дроту і табличні значення технічних характеристик нікель-титанового сплаву.

У разі прямого відрізка дроту (деформація тип а) виникає сила вигину, спрямована перпендикулярно до нігтьової пластини Fla (рис. 4).

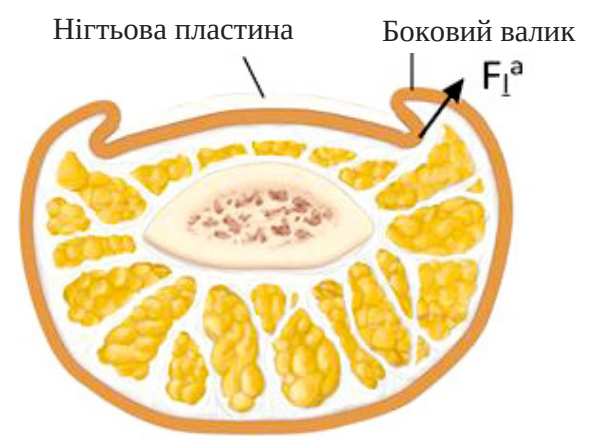

Рис. 4. Деформація прямого відрізка дроту з виникненням вигину перпендикулярно до нігтьової пластини Fla. 
Коли ми згинаємо сигмоподібну ділянку, то виникає дві вертикальні сили - сила вигину + сила крутіння, які підсумовуються в загальну вертикальну силу Fllb. Сигмоподібна ділянка дроту при активації створює також силу стиснення, спрямовану паралельно нігтьовій пластині Fllb. Результуюча сила буде розраховуватися за формулою fрез $=2 \sqrt{ }(\mathrm{F} \underline{\mathrm{l}} \mathrm{b}) 2+$ (Fllb) 2 (рис. 5).

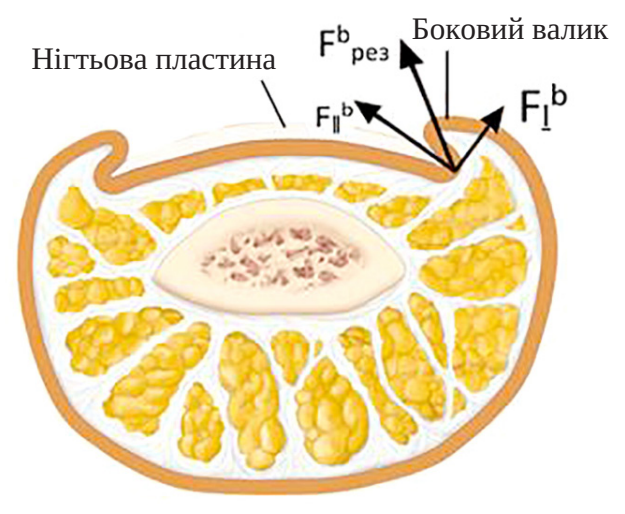

Рис. 5. Сила вигину + сила крутіння підсумовуються в загальну вертикальну силу Flb.

Як видно з даних рисунка 5, результуюча сила неначе витягає нігтьову пластину з бічного валика.

Таким чином швидше усувається запалення, зменшується ризик виникнення оніхолізису.

Наведемо оцінку значення сили, що діє на нігтьову пластину з боку звичайної дроту (тип деформації дроту а й а*). Еталонні значення сили витраченої на вигин дроту розраховані для дроту завдовжки 10 мм (рис. 6).

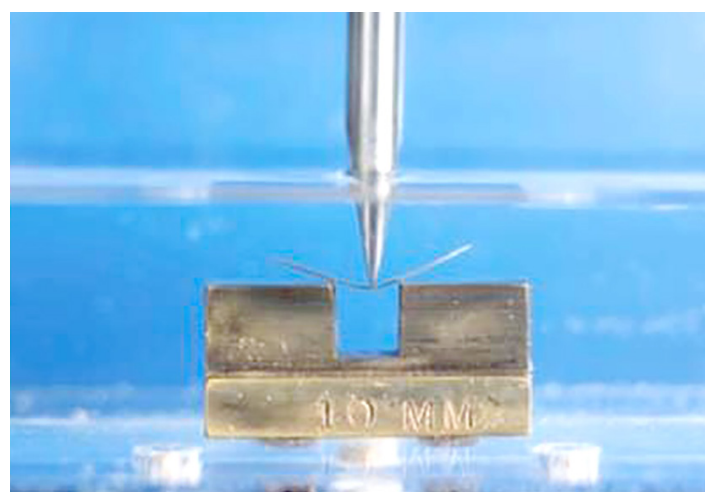

Рис. 6. Еталонні значення сили витраченої на вигин дроту розраховані для дроту довжиною 10мм

На графіку (рис. 7) показані значення сили витраченої на вигин дроту загальним розміром 10 мм (плече $\mathrm{l}=10 / 2=5$ мм).

Так, для прямого дроту діаметром 0,35 мм і завдовжки 10 мм (плече $\mathrm{l}=10 / 2=5$ мм) прогнути на 3 мм, це значення становить 80 грам для прогину

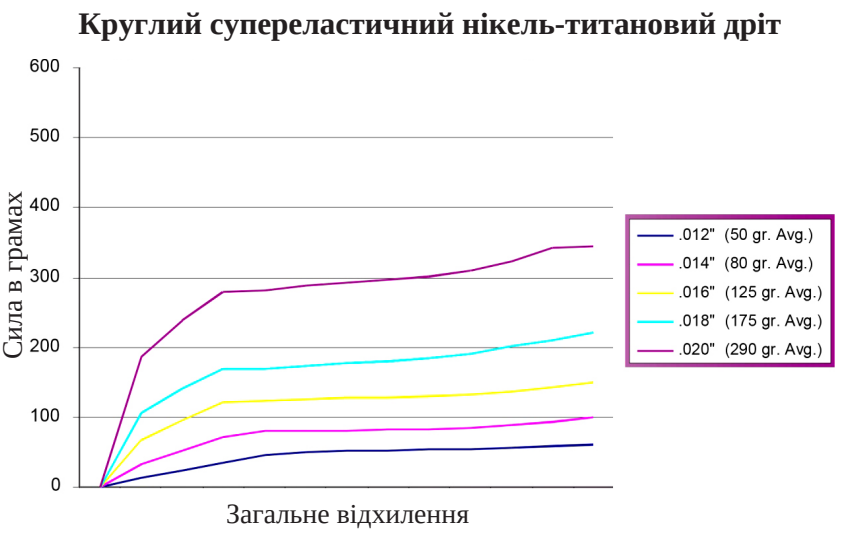

Рис. 7. Експериментальні залежності від загального прогину дроту величини зовнішнього навантаження, відповідний типу деформації дроту а й а*.

з боку зовнішньої сили і близько 40 грам для зворотної сили з боку дроту (тому що зворотна дія NiTi дроту приблизно вдвічі менша від початкової через явища гістерезису).

Згідно із законом Гука, для ії обчислення необхідно помножити коефіцієнт жорсткості на величину деформації. На практиці ми маємо справу з деформаціями, які значно перевищують деформації, які відповідають лінійній області залежності сили від прогину (закон Гука). 3 еталонних даних, наведених в даному графіку за NiTi видно, що отримати в такому випадку значення деформуючого дроту сили можна шляхом множення максимального значення сили в лінійній області приблизно вдвічі. Значення ж деформації в лінійній області можна отримати і таких міркувань: для дроту завдовжки 10 мм це значення було приблизно 0,24 мм, відповідно, для дроту завдовжки 19 мм можна брати 0,456 мм.

Для отримання конкретного значення сили, що діє на кожен край нігтьової пластини з боку дроту різного діаметра і при певних типах деформації, пропонуємо такі формули:

Fla $=586,7 \mathrm{x} \mathrm{d} 4 / \mathrm{l} 12$

Fla $*=1173,4 \times$ d 4 / 112

$\mathrm{F} \underline{\mathrm{l}} \mathrm{b}=492,33 \times \mathrm{d} 4 / \mathrm{l} 12 \times 1 /(1-\mathrm{R} / \mathrm{l} 1) 2$

$\mathrm{F} \| \mathrm{b}=1173,4 \mathrm{x} \mathrm{d} 4 / \mathrm{l} 22=32,6 \mathrm{~d} 4$ (Якщо $\mathrm{l} 2=2 \mathrm{R}$ $=6 \mathrm{MM})$.

У разі сигмоподібного дроту результуюча сила розраховується за формулою fрез $=2 \sqrt{ }(\mathrm{F} \underline{\mathrm{F}}) 2+$ (Fllb) 2.

Якщо ми хочемо отримати значення сили в грамах, то потрібно помножити отриманий результат на 101,94 т.к.1Н = 101,94 гр.

Обчислимо значення сили, що діє на кожен край нігтьової пластини з боку дроту різного діаметра при певних типах деформації (табл. 1). 
Таблиця 1. Обчислення значення сили, що діє на кожен край нігтьової пластини з боку дроту різного діаметра при певних типах деформації

\begin{tabular}{|c|c|c|c|}
\hline $\begin{array}{c}\text { Види сил при різних } \\
\text { видах деформації }\end{array}$ & $\begin{array}{c}\text { Значення сил у грамах } \\
\text { для проволоки d=0,30 mm } \\
l_{1}=9 \text { мм }\end{array}$ & $\begin{array}{c}\text { Значення сил у грамах для } \\
\text { проволоки d=0,35 mm } \\
l_{1}=9 \text { мм }\end{array}$ & $\begin{array}{c}\text { Значення сил у грамах для } \\
\text { проволоки d=0,40 mm } \\
l_{1}=9 \text { мм }\end{array}$ \\
\hline $\mathrm{F}_{\underline{1}}^{\mathrm{a}}$ & 5,98 & 11,07 & 18,90 \\
\hline $\mathrm{F}_{\underline{1}}^{\mathrm{a}^{*}}$ & 11,96 & 22,14 & 37,8 \\
\hline $\mathrm{F}_{\underline{1}}^{\mathrm{b}}$ при $\mathrm{l}_{2}=6 \mathrm{мм}$ & 11,32 & 20,96 & 35,79 \\
\hline $\mathrm{F}_{\|}^{\mathrm{b}}$ при $\mathrm{l}_{2}=6 \mathrm{мм}$ & 26,91 & 49,84 & 85,07 \\
\hline $\mathrm{F}_{\text {рез }}^{\mathrm{b}}$ при $\mathrm{l}_{2}=6 \mathrm{мм}$ & 29,19 & 54,07 & 92,29 \\
\hline
\end{tabular}

Для наочності, як змінюється, значення сили, що впливає на край нігтьової пластини залежно від діаметра дроту і типу вигину, наведемо наступний графік (рис. 8).

Значення дійсні для дроту завдовжки 19 мм (11 = 9 мм), при застосуванні сигмоподібного дроту, iї діаметр дорівнює 6 мм (12 = 6 мм). У разі сигмовидного дроту показані значення результуючої сили. Як ми бачимо, сила впливу на край нігтьової пластини у сигмоподібного дроту більша і різко зростає при збільшенні діаметра дроту.

Сила, що впливає на край нігтьової пластини залежно від діаметру дроту

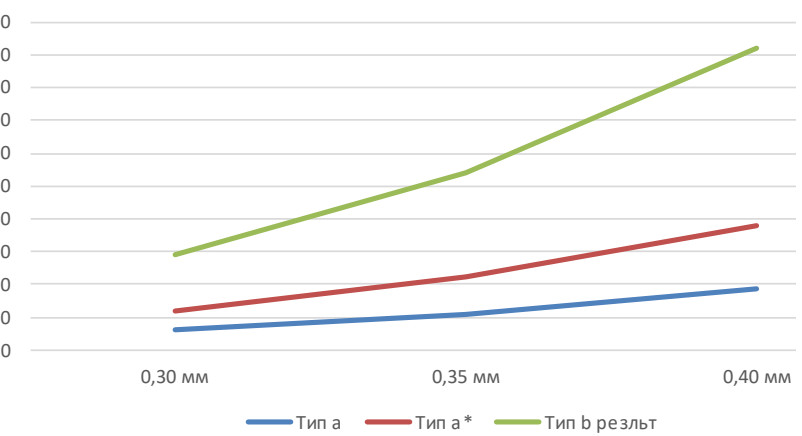

Рис. 8. Вплив на край нігтьової пластини залежно від діаметра дроту і типу вигину.

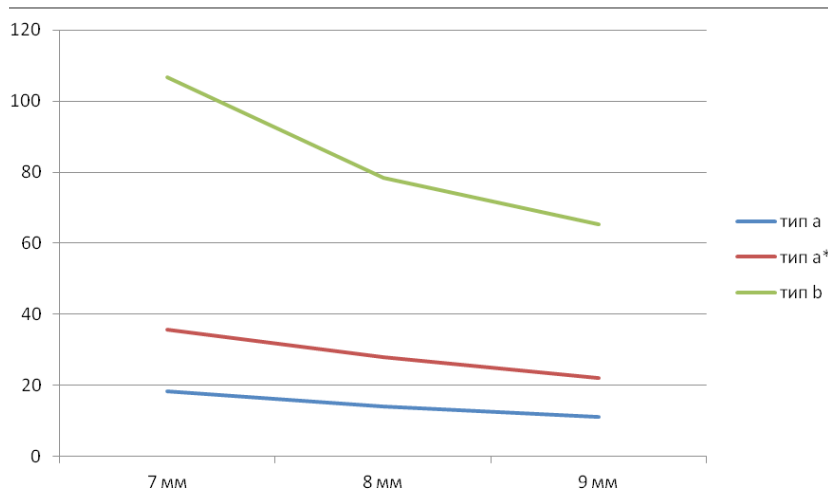

Рис. 9. Сила впливу дроту діаметром 0,35 мм залежно від ії довжини і типу деформації.
Цікаво також дізнатися, наскільки змінюється сила впливу на нігтьову пластину залежно від довжини дроту. Наведений нижче графік показує, як змінюється сила впливу дроту діаметром 0,35 мм залежно від її довжини і типу деформації (рис. 9).

Як видно з даних рисунка 9, чим менша довжина дроту, тим більша сила, яка впливає на нігтьову пластину.

Це слід враховувати майстру при роботі 3 врослими нігтями (рис. 10).

Одними із найсучасніших методів корекції врослого нігтя $€$ L-вкладка та ARKADA (рис. 11). Спосіб вирівнювання врослого нігтя, згідно з яким шліфують нігтьову пластину зі сторони врослого кута нігтя доти, поки нігтьова пластина зі сторони врослого кута нігтя стане еластичною, звільняють врослий кут нігтя з-під бокового валика шляхом підкладання вкладки з біоінертного матріалу під кут нігтя, з'єднують вкладку й кут нігтя шляхом нанесення матеріалу, висушують матеріал гарячим повітрям й надають нігтю естетичної форми,

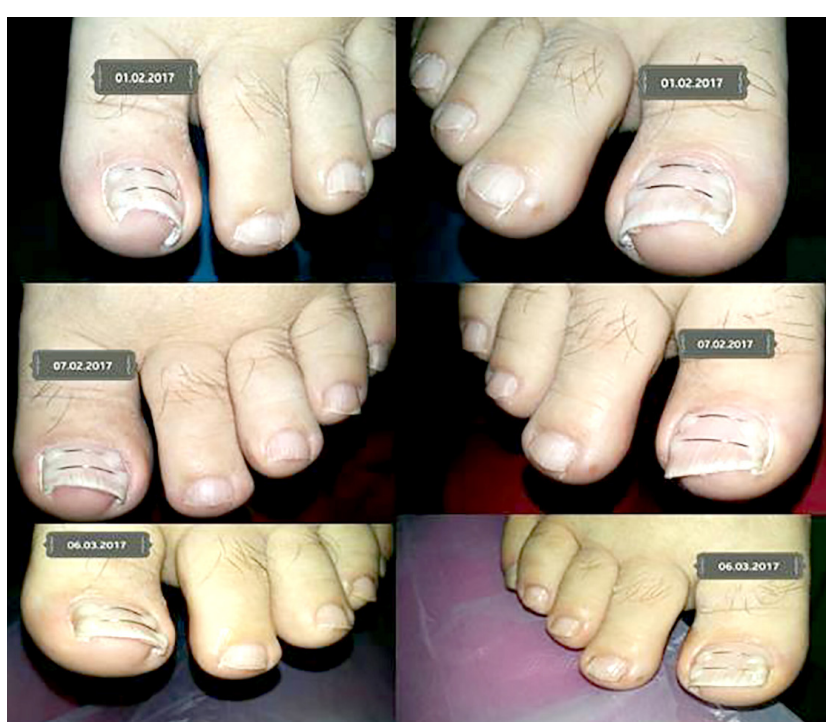

Рис. 10. Приклад лікування деформованого нігтя за допомогою нікель-титанової нитки. 


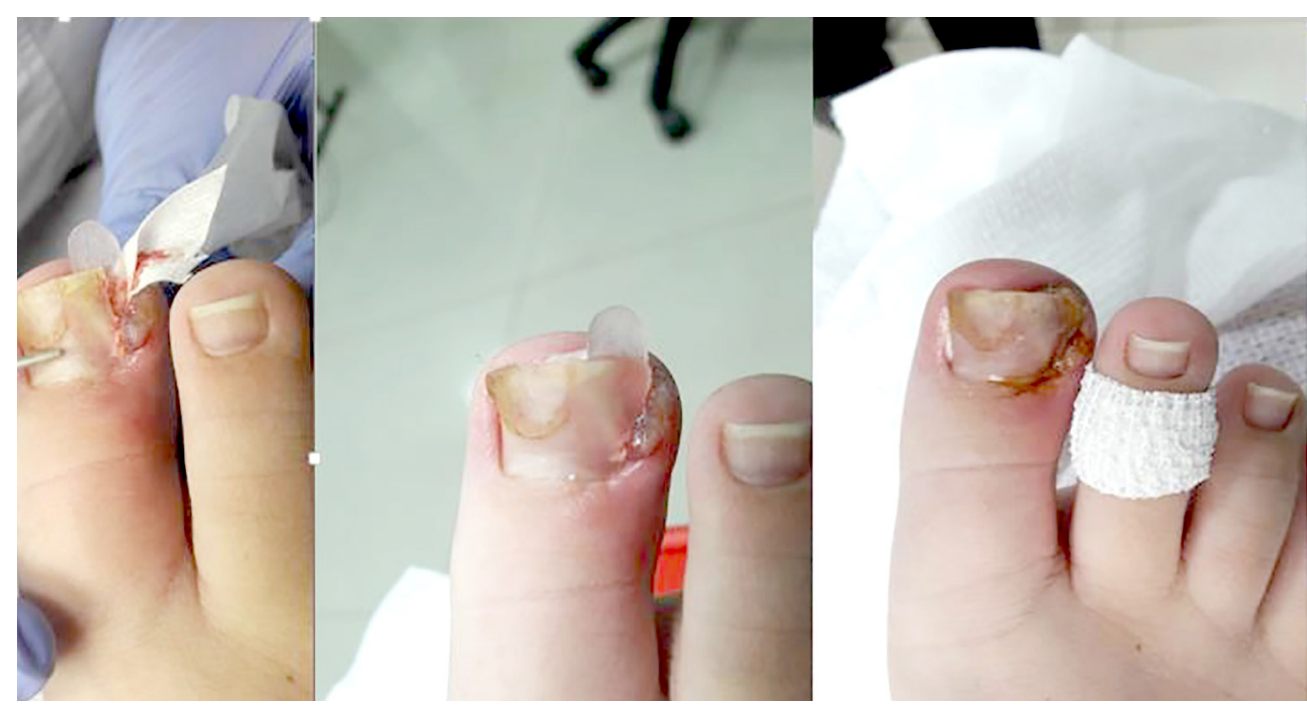

Рис.11. Лікування врослого нігтя за допомогою методу ARKADA i L-вкладок.

причому вкладка являє собою форму, яку отримують таким чином: з'єднують між собою акрилову пудру й мономер, надають суміші з акрилової пудри й мономеру форми, яка придатна для того, щоб її підкласти під кут нігтя, висушують форму гарячим повітрям; акрилова пудра у своєму складі містить одну або більше похідних метакрилату й прийнятні домішки, а мономер містить одну або більше похідних етиленгліколю, одну або більше похідних метакрилату й прийнятні домішки, причому матеріал, за допомогою якого з'єднують вкладку й кут нігтя, являє собою суміш, отриману шляхом з'єднання між собою акрилової пудри й мономеру, де акрилова пудра у своєму складі містить одну або більше похідних метакрилату й прийнятні домішки, а мономер містить одну або більше похідних етиленгліколю, одну або більше похідних метакрилату й прийнятні домішки.

Висновки. 1. Нікель-титановий дріт, на відміну від сталевої, діє з постійним зусиллям, яке практично не залежить від величини деформації.

2. Чим менше довжина дроту, тим більше її сила впливу на нігтьову пластину.

3. Чим більший діаметр дроту, тим більша їі сила впливу на нігтьову пластину.

4. При зміні довжини і діаметра сигмоподібного дроту її сила впливу на нігтьову пластину змінюється більш різко, ніж у прямій дроту.

\section{СПИСОК ЛІТЕРАТУРИ}

1. Гуров П. И. Опыт лечения вросшего ногтя. “История городского муниципального объединения им. С. П. Боткина и современное состояние специальной медпомощи / П. И. Гуров. - Орёл, 1999. - С. 163-164.
5. За інших рівних умов довжина і діаметр сигмоподібного дроту більше впливає на нігтьову пластину.

6. Напрям результуючої сили сигмоподібного дроту дозволяє витягати врослий ніготь 3 бічного валика.

7. Використання акрилових вкладок дозволяє одномоментно витягнути врослий контур без подальшої корекції.

8. Використання ортоніксії мінімізує витрати на лікування хворих на оніхокриптоз.

9. Ортонікія $є$ першочерговим методом вибору лікування врослого нігтя у хворих на цукровий діабет, оскільки впливає тільки на нігтьову пластину, не відбувається травми нігтьового валика та матриксу.

Таким чином, лікування врослого нігтя стає більш ефективним. Дані методики усувають недоліки інших систем та оперативних методик, оскільки одночасно діє на два патогенетичні фактори, а саме на нігтьову пластину, моделюючи її подальший ріст та на нігтьові валики, формуючи їх анатомічно під фізіологічну форму нігтьової пластини. Спираючись на клінічний досвід лікарів Київської міської клінічної лікарні № 6 та співробітників кафедри загальної та невідкладної хірургії НМАПО імені П. Л. Шупика, дані методики можна застосовувати в клінічній практиці лікарів Україні.

2. Ткаченко Г. К. Лечение вросшего ногтя / Г. К. Ткаченко // Здравоохранение Казахстана. - 1981. - № 1. - С. 58-59.

3. Лечение вросшего ногтя : тез. докл. / Н. Д. Томнюк, Г. В. Шагер // Вопросы гнойной хирургии. - Красноярск, 1981. - С. 74-76. 
4. Sonnex T. S. Treatment of ingrowing toenails with liguid spray cryotherapy / T. S. Sonnex, R. P. Dawber // BR. Med. J. Clin. Res. Ed. - 1985. - Vol. 291 (6489). - P. 173-175.

5. Фарыгин К. М. Транспозиция ногтевого ложа при вросшем ногте : матер. межрай. конф. / К. М. Фарыгин, А. В. Исайкин / Орёл, 1999. - Т. 4. - С. 602-604.

6. Мелешевич М. В. Причины рецидивов при лечении вросшего ногтя. XI пленум правления научного общества хирургов : тезисы докладов / М. В. Мелешевич. - Минск, 1972. - С. 246-247. 7. Шеклаков Н. Д. Болезни ногтей / Н. Д. Шеклаков. - М. : Медицина, 1975.

8. Sadr B. Ingrowing nail of a transplanted toe / B. Sadr // Hand. - 1982. - Vol. 14 (3). - P. 337192.

9. Samman P. O. Over-curvature of the nails. The Nails in Di serve. 3rd edition / P. O. Samman. - London. WmHeinemann. 1978. - 143 p.

\section{REFERENCES}

1. Gurov, P.I. (1999). Opyt lecheniya vrosshego nogtya. "Istoriya gorodskogo munitsipalnogo obyedineniya im. S. P. Botkina i sovremennoye sostoyaniye spetsialnoy medpomoshchi" [Experience of treating ingrown nail. "The history of the city municipal association by S.P. Botkin and the current state of special medical care"], Orel [in Russian].

2. Tkachenko, G.K. (1981). Lecheniye vrosshego nogtya [Treatment of ingrown nail]. Zdravookhraneniye Kazakhstana Healthcare of Kazakhstan, 1, 58-59 [in Russian].

3. Tomnyuk, N.D., \& Shager, G.V. (1981). Lecheniye vrosshego nogtya. Voprosy gnoynoy khirurgii [Treatment of ingrown nail. Questions of purulent surgery]. Theses of reports. Krasnoyarsk, 74-76 [in Russian].

4. Sonnex, T.S. (1985). Dawber-RP. Treatment of ingrowing toenails with liguid spray cryotherapy. BR. Med. J. Clin. Res. Ed., 20, 291 (6489), 173-175.

5. Farygin, K.M., \& Isaykin, A.B. (1999). Transpozitsiya nogtevogo lozha pri vrosshem nogte [Transposition of the nail bed with ingrown nail]. Proceedings of the International Conference, Orel, 4, (pp. 602-604) [in Russian].

6. Meleshevich, M.V. (1972). Prichiny retsidivov pri lechenii vrosshego nogtya. XI plenum pravleniya nauchnogo obshchestva khirurgov [Causes of recurrence in the treatment of ingrown nail. XI Plenum of the Board of the Scientific Society of Surgeons]. Abstracts. Minsk [in Russian].

10. Чашников А. А. Пересадка кожи по Парину при вросшем ногте / А. А. Чашников // Вестник хирургии им. И. И. Грекова. - 1956. - № 5. - С. 91-94.

11. Мелешевич А. В. Хирургическое лечение вросшего ногтя руководство для хирургов / А. В. Мелешевич, М. В. Мелешевич. - Гродно, 1993. - 80 с.

12. Арьев Т. Я. Отморожения / Т. Я. Арьев // Опыт советской медицины в Великой Отечественной войне 1941-1945 гг. M., 1951. - T. 1. - C. 191-193.

13. Weaver T. D. Multiple onychocryptosis following treatment of onychomycosis with oral terbinafine / T. D. Weaver, D. L. Jespersen // Cutis. - 2000. - Vol. 66, No. 3. - P. 211-212. 14. Анке Нидераю. Заболевание ногтей: учебное пособие; Пер. с немец ООО “Мирада”. - СПб. : Изд-во СПбГЭУ, 2015. -232 c.

7. Sheklakov, N.D. (1975). Bolezni nogtey [Diseases of the nails]. Moscow: Medishna.

8. Sadr, B. (1982). Ingrowing nail of a transplanted toe. Hand, 14 (3), 337-192.

9. Samman, P.O. (1978). Over-curvature of the nails. The Nails in Di serve. 3rd edition. London. WmHeinemann.

10. Chashnikov, A.A. (1956). Peresadka kozhi po Parinu pri vrosshem nogte [Parin skin transplantation for ingrown nail]. Vestnik khirurgii im. I. Grekova - Bulletin of Surgery by I. I. Grekov, 5, 91-94 [in Russian].

11. Meleshevich, A.V., \& Meleshevich, M.V. (1993). Khirurgicheskoye lecheniye vrosshego nogtya (rukovodstvo dlya khirurgov) [Surgical treatment of ingrown nail (guide for surgeons)]. Grodno [in Russian].

12. Aryev, T.Ya. (1951). Otmorozheniya. Opyt sovetskoy meditsiny $v$ Velikoy Otechestvennoy voyne 1941-1945 [Frostbite. Experience of Soviet medicine in the Great World War 19411945]. Moscow [in Russian].

13. Weaver, T.D., \& Jespersen, D.L. (2000). Multiple onychocryptosis following treatment of onychomycosis with oral terbinafine. Cutis, 66, 3, 211-212.

14. Anke Niderayu (2015). Zabolevaniye nogtey: uchebnoye posobiye [Nail disease: a textbook]. (OOO Mirada Transl. from German. SPb.: Izd-vo SPbGEU [in Russian].

Отримано 23.01.2019

\section{V. KRYZHEVSKIY1,2, O. O. TSYHANENKO ${ }^{2}$, M. V. SHEVCHUK ${ }^{2}$, Y. V. RYBIANETS ${ }^{2}$, R. V. IVANCHENKO², I. M. CHEGOL ${ }^{1}$, N. L. TOAN ${ }^{2}$, T. M. PULUPENKO ${ }^{3}$}

Kyiv City Clinical Hospital No. $6^{1}$

P. Shupyk National Medical Academy of Postgraduate Education ${ }^{2}$

National Technical University "I. Sikorskyi Kyiv Polytechnic Institute"3

\section{REVIEW OF CONSERVATIVE TREATMENTS FOR INGROWN NAIL}

The aim of the work: to give an example of the use of minimally invasive treatment methods - orthoxyxia (CM, titanium thread, L-tab, ARKADA) in the treatment of onychocryptosis (ingrown nail).

Materials and Methods. Minimally invasive orthonic methods on the basis of Kyiv City Clinical Hospital No. 6 during 2012-2018 . 
Results and Discussion. Full restoration of the nail plate and elimination of ingrown nail plates with minimally invasive orthonic intervention. Thus, the treatment of an ingrown nail becomes more effective. These techniques eliminate the drawbacks of other systems and operational techniques, since they simultaneously affect two pathogenetic factors, namely the nail plate, simulating its further growth, and nail rollers, forming them anatomically under the physiological shape of the nail plate. Based on the clinical experience of the doctors of the Kyiv City Clinical Hospital No. 6 and the staff of the Department of General and Emergency Surgery, P. Shupyk National Medical Academy of Postgraduate Education, we can say that these methods can be applied in the clinical practice of Ukrainian doctors.

Key words: oniocryptosis; ingrown nail; clinical case; ARKADA method.

В. В. КРИЖЕВСКИЙ ${ }^{1,2}$, А. О. ЦЫГАНЕНКО ${ }^{2}$ М. В. ШЕВЧУК ${ }^{2}$ Ю. В. РЫБЯНЕЦ², Р. В. ИВАНЧЕНКО ${ }^{2}$, И. Н. ЩЕГОЛЬ ${ }^{1}$, Н. Л. ТОАН ${ }^{2}$ Т. Н. ПИЛИПЕНКО ${ }^{3}$

Киевская городская клиническая больница № $6^{1}$

Национальная медицинская академия последипломного образования имени П. Л. Шупика², Киев

Национальный технический университет Украины "Киевский политехнический институт имени Игоря Сикорского"з

\section{ОБЗОР КОНСЕРВАТИВНЫХ МЕТОДОВ ЛЕЧЕНИЯ ВРОСІЕЕО НОГТЯ}

Приведен пример использования малоинвазивных методов лечения - ортониксия (ЗТO, титановая нить, L-Bкладка, ARKADA) при лечении онихокриптоза (вросшего ногтя). Малоинвазивные ортониксические методы применяли на базе КМКЛ № 6 на протяжении 2012-2018 гг. Достигнуто полное восстановление ногтевой пластины и устранения врастания ногтевых пластин при малоинвазивном ортониксическом вмешательстве. Лечение вросшего ногтя становится более эффективным. Данные методики устраняют недостатки других систем и оперативных методик, поскольку одновременно действует на два патогенетических фактора, а именно на ногтевую пластину, моделируя ее дальнейший рост, и на ногтевые валики, формируя их анатомически под физиологическую форму ногтевой пластины. Благодаря клиническому опыту врачей Киевской городской клинической больницы № 6 и сотрудников кафедры общей и неотложной хирургии НМАПО имени П. Л. Шупика, можно сказать, что данные методики могут применяться в клинической практике врачей Украины.

Ключевые слова: онихокриптоз; вросший ноготь; клинический случай; метод ARKADA. 